\title{
Viability of Peranakan Etawah Liquid Semen Preserved in Tris Substituted with Various Energy Sources
}

\author{
Zakiya NAH, Yanti AH, Setyawati TR \\ Department of Biology, Faculty of Mathematics and Natural Science, University of Tanjungpura, Pontianak \\ E-mail:nurulafzanhz@gmail.com
}

(received 22-08-2019; revised 27-01-2020; accepted 28-01-2020)

\begin{abstract}
ABSTRAK
Zakiya NAH, Yanti AH, Setyawati TR. 2020. Daya simpan semen cair kambing Peranakan Etawah dalam tris yang disubstitusi dengan sumber energi berbeda. JITV 25(2): 68-73. DOI: http://dx.doi.org/10.14334/jitv.v25i2.2026

Pengunaan semen cair untuk keperluan inseminasi buatan pada kambing Peranakan Etawah (PE) merupakan alternatif untuk menggantikan semen beku yang produksinya terkendala sarana yang terbatas dan mahal. Produksi semen cair lebih cepat dibandingkan semen beku, tetapi masa simpan semen cair yang dipreservasi dengan media pengencer standar seperti tris kuning telur sangat singkat. Tujuan penelitian ini adalah untuk mengetahui viabilitas semen kambing PE dalam pengencer tris kuning telur yang disubstitusi sumber energi berupa glukosa, galaktosa, dan manosa serta sumber energi yang paling efisien untuk preservasi semen. Penelitian ini dilaksanakan pada bulan Agustus hingga September 2018 di Balai Inseminasi Buatan Lembang, Jawa Barat. Penelitian ini didesain dengan rancangan acak kelompok (RAK) yang terdiri atas tiga perlakuan yang dibagi menjadi lima kelompok. Semen segar kambing PE dipreservasi menggunakan media pengencer yang telah dimodifikasi sumber energinya. Hasil penelitian menunjukkan bahwa penggunaan glukosa pada media pengencer semen kambing PE menghasilkan motilitas terbaik di antara perlakuan lainnya $(64,29 \pm 9,2 \%)$. Viabilitas tertinggi ditemukan pada media pengencer dengan substitusi fruktosa $(86,76 \pm 2,3 \%)$. Viabilitas semen cair yang paling lama ditemukan pada media pengencer dengan substitusi glukosa yaitu dengan masa simpan enam hari.
\end{abstract}

Kata Kunci: Glukosa, Semen Cair, Motilitas, Kambing PE, Viabilitas

\begin{abstract}
Zakiya NAH, Yanti AH, Setyawati TR. 2020. Viability of Peranakan Etawah liquid semen preserved in tris substituted with various energy sources. JITV 25(2): 68-73. DOI: http://dx.doi.org/10.14334/jitv.v25i2.2026

The use of liquid semen for artificial insemination program of Etawah crossbreed goat (PE) is an alternative to replace frozen semen which is constrained by limited and expensive facilities. Production of liquid semen is faster than frozen semen, but the viability of liquid semen which preserved with a standard extender such as tris egg yolk is very short. The purpose of this study was to determine the viability of PE goat semen in egg yolk tris substituted with energy sources such as glucose, galactose, and mannose and to determine the most efficient energy source for semen preservation. This research was conducted from August to September 2018 at the Artificial Insemination Center in Lembang, West Java. This study was designed in a randomized block design (RBD) consist of three experimental groups divided into five groups. Fresh semen of PE goats were preserved using extender which energy source has been modified. Results showed that using glucose in PE goat semen extender produced the best motility among other groups $(64.29 \pm 9.2 \%)$. The highest viability was found in extender with fructose substitution $(86.76 \pm 2.3 \%)$. The longest viability of liquid semen was found in the extender with glucose substitution. It lasted for six days.
\end{abstract}

Key Words: Glucose, Liquid Semen, Motility, PE Goat, Viability

\section{INTRODUCTION}

Peranakan Etawah (PE) goat is a type of dairy goat that has high productivity. The demand for PE goat milk has increased since it is considered to contain richer nutrition compared to cow's milk, such as higher phosphor and has even been recommended as a milk substitution for infants, children, and adults who are allergic to cow's milk. This PE goat demand could be fulfilled through artificial insemination.
Artificial Insemination (AI) is a reproductive technology that is able to improve genetic quality of livestock and produce good quality offspring by utilizing superior males. AI involves males' semen to be taken and preserved to become frozen semen or liquid semen. Frozen semen treatment is sometimes constrained by the availability of facilities such as containers and liquid nitrogen for cryopreservation. In addition, Herdiawan (2004) stated that the quality of spermatozoa in frozen cow semen decreased by around 
$30-60 \%$. The decline in quality can be seen from a decrease in viability up to $70 \%$ and low fertility of surviving spermatozoa.

The quality of liquid semen for AI is very dependent on the extender. One of the main components in the extender is nutrition, such as an energy source for spermatozoa endurance.

Rehman et al. (2013) stated that various kinds of sugar can be used as semen nutrition, such as glucose, trehalose, ribose, raffinose, saccharose, galactose. Carbohydrates commonly used in semen extender to maintain motility for longer spermatozoa are monosaccharides. The effectiveness of various types of monosaccharides in semen extender can be different because each monosaccharide crosses a different reaction path. This study aims to determine the viability of EC goat semen in tris egg yolk extender substituted with energy sources such as glucose, galactose, and mannose; and to find out the best type of energy source in EC goat semen extender.

\section{MATERIALS AND METHODS}

\section{Semen collection and preservation}

Semen was obtained from two 6-year-old male Etawah goats weighing $70 \mathrm{~kg}$. The goat's semen is collected using an artificial vagina to obtain two ejaculates each. The semen used for preservation must meet the following requirements, namely thick to moderate consistency, spermatozoa motility $\geq 70 \%$, spermatozoa concentration more than $2.5 \times 10^{9}$, and total spermatozoa abnormalities $\leq 20 \%$ (Arifiantini 2012). Fresh semen from one ejaculate is divided into four parts and diluted each with different diluents (Table 1). The diluted semen is then packaged in a tube and stored in a refrigerator at $4^{\circ} \mathrm{C}$.

\section{Semen assessment}

Assessment is done on fresh semen and post preservation semen. Fresh semen evaluation covers all macroscopic and microscopic aspects. The macroscopic evaluation includes volume, color, consistency (with thick, moderate, watery criteria), and degree of acidity $(\mathrm{pH})$. The microscopic evaluation includes motility, concentration, viability, and spermatozoa abnormalities. Evaluation of post preservation semen includes motility, viability, and abnormal spermatozoa every 24 hours until spermatozoa motility reaches $50 \%$.

Motility assessment is done by homogenizing one drop of fresh semen with three drops of physiological $\mathrm{NaCl}$ on the object-glass and covered with a glass cover and assessed subjectively using a microscope with 200 times magnification. The proportion of progressively active spermatozoa and those that are passive are compared. Spermatozoa concentrations are assessed by the Neubauer counting chamber.

Observation of viability and abnormality is done by making semen smear using eosin $2 \%$. One drop of semen was dropped on the object-glass, then 3 drops of semen were dropped on it and homogenized, then a smear was made. The object-glass is dried on a heating table at $\pm 40^{\circ} \mathrm{C}$ for 5 minutes. The preparations are observed at magnification 400 times under a microscope. Observation of viability and abnormality was carried out by observing 200 spermatozoa minimum.

\section{Data analysis}

Data in the form of motility, viability, and spermatozoa abnormalities in each treatment were analyzed with SPSS Statistics 23. A comparison of each treatment group was tested with two-way ANOVA and followed by Duncan's test with $95 \%$ confidence level.

\section{RESULTS AND DISCUSSION}

\section{Quality of goat fresh semen}

The assessment results showed that all macroscopic and microscopic factors of fresh semen were normal and qualified for the preservation stage (Table 2). Fresh semen looks creamy. This is in line with the statement of Ariantie et al. (2014) which states that PE goat semen is generally creamy. In fact, according to Arifiantini (2012), healthy goat semen has a broader spectrum of colors, ranging from milky white, creamy, to clear. The volume of semen ranges from $1-.5$ $\mathrm{ml} /$ ejaculate with an average volume of 1.4 $\mathrm{ml} /$ ejaculate. This volume is within the normal range for goat semen. According to Arifiantini (2012), the normal volume of goat semen ranges from $0.5-2$ $\mathrm{ml} /$ ejaculate. The average $\mathrm{pH}$ of semen is 6.84 . The value is still within the normal range for goat semen, which is 6.4-7.2 (Ramukhithi et al. 2011). The consistency of semen is thick and quite normal.

The percentage of fresh semen motility of PE goats ranged from $70-80 \%$ with an average value of $74 \%$. This value is classified as normal and meets the minimum motility standard allowed for the preservation stage, which is $70-90 \%$ Arifiantini (2012). The average concentration of spermatozoa in fresh semen is normal, which is $2.48 \times 10^{9} / \mathrm{ml}$ and ranges from 2.5$2.545 \times 10^{9} / \mathrm{ml}$. According to Ariantie et al. (2014), PE goat spermatozoa concentrations were in the range of $2.4-3.5 \times 10^{9} / \mathrm{ml}$. This value allows the semen to proceed to the preservation stage which requires a minimum concentration of $2.5 \times 10^{9} / \mathrm{ml}$. 
Table 1. Composition of extender

\begin{tabular}{lcccc}
\hline \hline \multirow{2}{*}{ Composition } & \multicolumn{4}{c}{ Variation on extender } \\
\cline { 2 - 5 } & $\mathrm{K}$ & $\mathrm{P}_{1}$ & $\mathrm{P}_{2}$ & $\mathrm{P}_{3}$ \\
\hline Tris aminomethan (g) & 0.6 & 0.6 & 0.6 & 0.6 \\
Citric acid monohydrate (g) & 0.33 & 0.33 & 0.33 & 0.33 \\
Energy source: & & & & \\
Fructose (g) & 0.4 & 0 & 0 & 0 \\
Glucose (g) & 0 & 0.4 & 0 & 0 \\
Galactose (g) & 0 & 0 & 0.4 & 0 \\
Manose (g) & 0 & 0 & 0 & 0.4 \\
Aquabidest (ml) & 20 & 20 & 20 & 20 \\
Yolk (ml) & 4 & 4 & 4 & 4 \\
Penicillin (g) & 3 & 3 & 3 & 3 \\
Streptomycin (g) & 3 & 3 & 3 & 3 \\
\hline
\end{tabular}

Table 2. Average value of goat fresh semen quality tested macroscopic and microscopic

\begin{tabular}{lcc}
\hline \hline Assessment & Value & Criteria \\
\hline Macroscopy & & \\
Colour & Creamy & Normal \\
Volume (ml) & 1.4 & Normal \\
$\mathrm{pH}$ & 6.84 & Normal \\
Consistency & Thicky & Normal \\
\hline Microscopy & & \\
Motility (\%) & 74 & Normal \\
Concentration $\left(\mathrm{x} 10^{9} / \mathrm{ml}\right)$ & 2.4802 & Normal \\
Viability $(\%)$ & 85.6 & Normal \\
Abnormality $(\%)$ & 1.3 & Normal \\
\hline
\end{tabular}

Table 3. Motility, viability, and abnormality of post preservation semen

\begin{tabular}{lccc}
\hline \hline Extender & Motility $(\%)$ & Viability $(\%)$ & Abnormality $(\%)$ \\
\hline K (fructose) & $58.43 \pm 9.9^{\mathrm{a}}$ & $86.76 \pm 2.3^{\mathrm{a}}$ & $0.57 \pm 0.6^{\mathrm{a}}$ \\
$\mathrm{P}_{1}$ (glucose) & $64.29 \pm 9.2^{\mathrm{b}}$ & $82.83 \pm 3.6^{\mathrm{b}}$ & $0.51 \pm 0.6^{\mathrm{a}}$ \\
$\mathrm{P}_{2}$ (galactose) & $56.57 \pm 8.7^{\mathrm{a}}$ & $83.56 \pm 3.8^{\mathrm{b}}$ & $0.56 \pm 0.6^{\mathrm{a}}$ \\
$\mathrm{P}_{3}$ (mannose) & $57.71 \pm 9.6^{\mathrm{a}}$ & $81.69 \pm 3.7^{\mathrm{b}}$ & $0.53 \pm 0.7^{\mathrm{a}}$ \\
\hline
\end{tabular}

The viability of fresh semen was in the range of $70-92 \%$ with an average of $85.6 \%$. The percentage of total spermatozoa abnormalities ranged from $0.5-3 \%$ with an average of $1.3 \%$. In addition, all abnormalities found in the form of folded tail and classified as secondary abnormalities. Based on Purwantara et al. (2010), reference to the INS-Indonesian National Standard which allows a maximum of $20 \%$ sperm abnormality rate including both primary and secondary abnormalities, it is expected that the primary sperm 


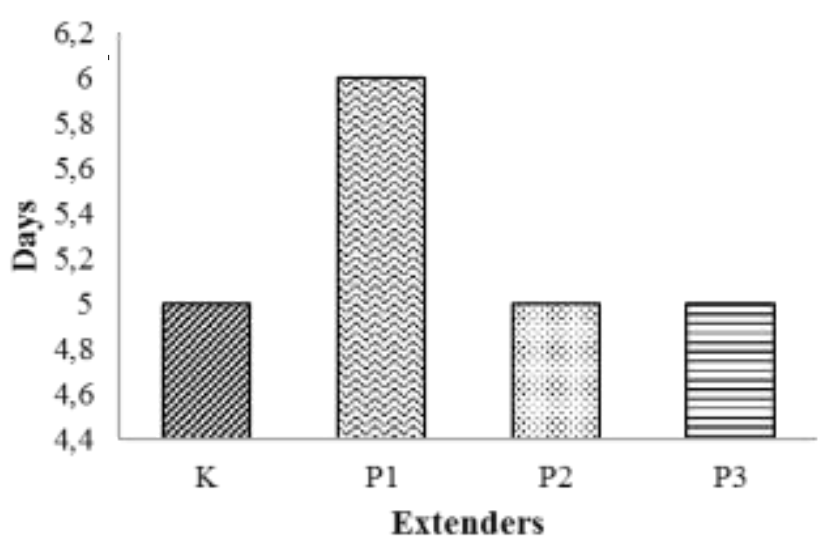

Figure 1. Storage age of goat semen in various extenders

abnormality rate does not exceed $10 \%$. Thus, the abnormality value is still classified as normal and qualifies for preservation because of the total abnormal spermatozoa $\leq 20 \%$ (Arifiantini 2012).

\section{Quality of goat on post preservation semen}

The spermatozoa motility of the P1 extenders was significantly different when compared to the $\mathrm{K}, \mathrm{P} 2$, and P3 extenders. The highest motility $(64.29 \pm 9.2 \%)$ occurred in P1 extenders, followed by $\mathrm{K}$ extenders

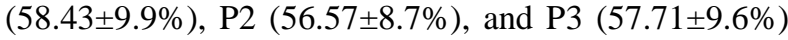
(Table 3). This is in line with the statement of Maisse (1994) in Nynca et al. (2016) who concluded that fructose and glucose are comparable in terms of its value as an extender.

The superiority of glucose as an energy source was also evidenced by the longer storage age of the P1 extender, which lasted for six days. This calculation was based on how long the spermatozoa able to maintain the motility percentage above $50 \%$. Motility parameters represent the activeness of spermatozoa in movement (motile) and the nature of the life of the cell so that it is appropriate to be benchmark viability of semen. Extenders $\mathrm{K}$ and $\mathrm{P} 3$ were recorded to last only for five days before their motility dropped below $50 \%$. Nevertheless, the initial motility of extenders K, P1, P2, and $\mathrm{P} 3$ is almost the same, which ranged $70-74 \%$.

The use of glucose as an energy source for spermatozoa cells involves the conversion of glucose into fructose first. Glucose is reduced to sorbitol through the enzyme aldose reductase. Sorbitol then dehydrogenates and forms fructose by sorbitol dehydrogenase. The result of fructose will be metabolized via the glycolysis pathway. Fructose gets a phosphate donor with a phosphofructokinase to fructose bisphosphate. The aldolase enzyme breaks down fructose bisphosphate into glyceraldehyde-3-phosphate
(G3P). G3P forms 1,3-bisphosphoglycerate by dehydrogenase. The kinase enzyme converts 1,3-BPG to phosphoglycerate. The enzyme phosphoglycerate converts phosphoglycerate to phosphoenolpyruvate. The conversion of pyruvate phosphoenol to pyruvate by the pyruvate kinase enzyme is an exergonic reaction that produces 2 ATP.

Galactose and mannose substitutions had no significant effect on maintaining spermatozoa motility (Table 3). The utilization of galactose and mannose by cells is preceded by an overhaul involving various enzymes (McKee \& McKee 2011). The two monosaccharides should be broken down to become fructose, then undergo a glycolysis reaction to form energy. Galactose reshuffle begins with the conversion of galactose to galactose-1-phosphate (G1P) through the galactokinase enzyme. The galactose-1-phosphate uridylyltransferase enzyme converts G1P into uridine diphosphate galactose (UDPGal). This compound is the intermediary that converts galactose to glucose. UDPGal through the enzyme UDP-galactose-4epimerase produces UDP-glucose (UDPGlu) which is then converted to glucose-1-phosphate (G1P). The compound undergoes phosphate donors via phosphoglucomutase to glucose-6-phosphate (G6P) enzyme. G6P is converted to fructose and then fructose passes through the glycolysis pathway to produce energy. Likewise, mannose must be converted to fructose-6-phosphate (F6P) by hexokinase to start the glycolysis reaction.

The amount of energy produced by galactose and mannose is the same as the amount of energy produced by glucose and fructose, which is 2 ATP. However, the breakdown of galactose and mannose must be preceded by the conversion of these compounds into fructose so that the glycolysis reaction can begin. This process will delay energy consumption by cells which can result in the death of spermatozoa. Dead spermatozoa can become toxic substances and increase free radicals 
(Setiadi et al. 2000). This condition can poison other spermatozoa and will gradually reduce the value of motility as well as the viability of spermatozoa.

The success of fertilization and insemination is determined not only by motility but also by the viability or viability of spermatozoa cells. The ability to survive these cells is much influenced by environmental conditions that exist, both from the natural conditions of the female reproductive organs and seminal plasma and artificial conditions such as the addition of semen extenders (if intended for artificial insemination activities). The addition of extenders and their modification into semen aims to extend the life span of cells so that cells can last longer and the probability of conception increases.

The percentage of spermatozoa viability of $\mathrm{K}$ extender substituted by fructose was significantly different from those of P1, P2, and P3 extender, with an average of $86,76 \pm 2.3 \%$. Apart from being a source of energy, fructose is a monosaccharide that can be used as cryoprotectant agents to avoid cold shock to cells. Bucak et al. (2012) state that cold shock is one of sublethal damage which emerge with other condition, they are ice crystal formation, oxidative stress, osmotic changes and lipid-protein reorganizations within the cell membranes, resulting in the loss of motility and viability. Cold shock can be prevented through the composition of air in cells. Water molecules in the cell can be substituted by fructose so that the cell is more stable during the temperature transition to the preservation period. This also happens as the sugar prevents sperm cells against cold shock during cold storage at extreme temperatures (Rehman et al. 2013). Cell membranes help in maintaining internal conditions and physiological activities to keep them running normally.

Water substitution by sugar also occurs in monosaccharides such as glucose, galactose, and mannose. However, spermatozoa cells more quickly substitute monosaccharides of the same type as it has low molecular weight molecules that lead to the ability to pass through the plasma membrane of spermatozoa and provide energy to function in metabolism and normal physiological manner (Naing et al. 2010) Monosaccharides from extender are used by cells just before the seminal plasma fructose runs out to use energy and save cells from cold shock. Therefore, the viability of extender P1, P2, and P3 is still relatively high (Table 3 ). This can be caused by monosaccharides in these three types of extender can still be used by cells as energy sources and cryoprotectant agents.

The reduced water composition after monosaccharides substitute water in the cell plasma will prevent crystallization and tear in the plasma membrane. This is caused by the ability of energy sources (sugar) as a cryoprotectant agent. This agent prevents the spermatozoal membrane from integrity damage which could consequently interfere with the fertilizing capacity of spermatozoa (Bohlooli et al. 2012)

Spermatozoa abnormalities were found in all extenders, although the percentage was very small and not significantly different between groups (Table 3 ). Different types of extenders do not have an impact on the tendency for abnormal spermatozoa. Besides, there was no significant increase in the percentage of abnormalities. This indicates that morphological abnormalities in spermatozoa are disorders that have occurred before semen is ejaculated.

All recorded abnormalities are folded tail types and are classified as secondary abnormalities. According to Susilawati (2011), secondary abnormalities can occur after spermatogenesis up to ejaculation and in the processing stage either. Disorders experienced by spermatozoa can be in the form of chemical factors such as contamination with urine or blood or physical factors such as heating that can take place during postejaculatory treatment. A very small percentage of abnormalities in this study were caused by the use of sterile semen collection tools and proper postejaculation treatment. Prevention of contamination of the semen is done by sterilizing the artificial vagina before use. Besides, the goat is always bathed before the collection of semen. Such treatment can minimize the possibility of exposure to spermatozoa from contaminants so that secondary abnormalities can be avoided.

\section{CONCLUSION}

In conclusion, this study demonstrated that substitution of glucose in tris extender for Peranakan Etawah liquid semen can maintain the storage age longer among other extenders up to six days and show up the highest motility and the lowest abnormality. However, further studies still needed to observe the effect of glucose substitution in various concentrations.

\section{ACKNOWLEDGEMENT}

The author would like to thank Artificial Insemination Center, Lembang, West Java for the permission to use laboratory facilities.

\section{REFERENCES}

Ariantie OS, Yusuf TL, Sajuthi D, Arifiantini RI. 2014. The quality of etawah crossbreed buck liquid semen in modified tris diluents with trehalose and raffinose. J. Vet. 15:11-22. 
Arifiantini RI. 2012. Teknik koleksi semen dan evaluasi semen pada hewan. Bogor (Indones): Institut Pertanian Bogor Press.

Bohlooli S, Cedden F, Jang JP, Razzaghzadeh S, Bozoglu S. 2012. The effect of different extenders on post-thaw sperm viability, motility and membrane integrity in cryopreserved semen of zandi ram. J. Basic Appl. Sci. Res. 2:1120-1123.

Bucak MN, Başpinar N, Tuncer PB, Çoyan K, Sariözkan S, Akalin PP, Büyükleblebici S, Küçükgünay S. 2012. Effects of curcumin and dithioerythritol on frozenthawed bovine semen. Andrologia. 44:102-109.

Herdiawan I. 2004. Pengaruh laju penurunan suhu dan jenis pengencer terhadap kualitas semen beku domba Priangan. JITV. 9:98-107.

Maisse G. 1994. Comparison of different carbohydrates for the cryopreservation of rainbow trout (Oncorhynchus mykiss) sperm. Aquat. Living Resour. 7:217-219.

McKee T \& McKee JR. 2011. Biochemistry: The molecular basis of life. Boston (UK): Oxford University.

Naing SW, Wahid H, Azam KM, Rosnina Y, Zuki AB, Kazhal S, Bukar MM, Thein M, Kyaw T, San MM. 2010. Effect of sugars on characteristics of Boer goat semen after cryopreservation. Anim. Reprod. Sci. 122:23-28.

Nynca J, Judycka S, Liszewska E, Dobosz S, Grudniewska J, Arai K, Fujimoto T, Ciereszko A. 2016. Utility of different sugar extenders for cryopreservation and postthaw storage of sperm from Salmonidae species. Aquaculture. 464: 340-348.

Purwantara B, Arifiantini RI, Riyadhi M. 2010. Sperm morphological assessments of Friesian Holstein bull semen collected from three Artificial Insemination centers in Indonesia. J. Indones. Trop. Anim. Agric. 35:90-94.

Ramukhithi FV, Nedambale TL, Sutherland B, Lehloenya KC. 2011. Cryopreservation of South African indigenous goat semen. African J. Biotechnol. 10:17898-17902.

Rehman FU, Zhao C, Shah MA, Qureshi MS, Wang X. 2013. Semen extenders and artificial insemination in ruminants. Veterinaria. 1:1-8.

Setiadi B, Sutama IK, Situmorang P, Supriyati, Adiati U, Budiarsana IGM, Kostaman T, Maulana, Mulyawan. 2000. Evaluasi Karakteristik Semen Kambing Calon Bibit. Bogor (Indones): Balai Penelitian Ternak.

Susilawati, T. 2011. Spermatology. Malang (Indones): Universitas Brawijaya Press. 